\title{
SOCIAL CAPITAL MAKING THROUGH LOCAL INSTITUTION: A VILLAGE COMMUNITY EMPOWERMENT STRATEGY IN THE PULAU BUAYA VILLAGE, EAST NUSA TENGGARA OF INDONESIA
}

\author{
Djaha Ajis Salim Adang*, Lino Maria M., Mau Alfred Ena \\ Public Administration Department, Faculty of Social and Political Sciences, \\ University of Nusa Cendana, Indonesia \\ *E-mail: ajissalim@yahoo.com
}

\begin{abstract}
Solidarity of rural communities is a form of social capital which needs to be maintained, developed, and preserved in all aspects of village life. One of the social capital in the implementation of village development is independence and participation of village communities. In Pulau Buaya Village, there are two institutions that maintain, develop and preserve community participation in the village. These are adat (customary) and religious institutions. "Gotong royong (mutual cooperation) is associated with customary or religious activities, even the sick endeavor to participate in an activity". Failure in participation results in expulsion from the life of the village community (social sanction) hence causes embarrassment, disturbed self-esteem in the eyes of members of the village community. No matter how small the activity conducted by village government is, the participation shown is false participation. Activity participation was due to money or counter-achievement. Thus empowerment of social capital at the village level requires local institutions that ensure social capital need to be involved in various village policy formulations. Therefore the village government needs to involve local institutions (religion and adat) to empower social capital in the village.
\end{abstract}

\section{KEY WORDS}

Empowerment, social capital, local institutions, village, community.

The government of Jokowi and Jusuf Kalla has launched the village development as a motor of national development with the motto of " Desa kuat Indonesia hebat; Desa hebat, Indonesia hebat" (Great Strong Indonesian Village; Great Village, Great Indonesia). To make Indonesia strong and powerful, it must build the village into a strong and powerful village (Sudjatmiko and Zakaria, 2015). Policies which pays more attention to rural areas are also reasonable because most of the Indonesian population inhabit rural areas. Therefore some authors have suggested that village development should start from the village level (Chambers, 1987); change should start from the bottom - from the village (Ife and Tesoriero, 2008). A number of reasons were put forward to substantiate this argument, among which the villagers knew what their needs were.

The Indonesian government is aware of this. Therefore, various policies for the process of accelerating village development have been established. After Law No. 6 of 2014 (Law 6/2014) on the Village, followed by Government Regulation No. 43 of 2014 (PP 43/2014) amended by PP 47/2014 on Implementation of Law 6/2014, Ministerial Regulation (Permen) Desa , Regions and Transmigration No. 3 of 2015 on Village Guidance, Ministry of Marine and Fisheries No. 10 of 2014 on Guidelines for the Implementation of National Program for Self-reliance Empowerment of Marine and Fisheries. There are more government policies on village development and governance. All these policies position villages as the subject of development, not as objects of development.

Giving village government and communities more roles to take part, take their own initiative to do whatever they need with the support of their own funds, funds from the central government through the State Budget (APBN), provincial and district / municipal governments through the Revenue Budget and Regional Expenditure (APBD) and third-party funding sources is a good step. However, the condition of villages and villagers who tends to be 
powerless caused all parties involved worried about the ability of the village government and communities.

A number of the following studies indicate that village government and communities need to be empowered to carry out their assigned tasks. (1) The people of the villages of Pulau Buaya and Uma Pura, formerly known as gotong-royong or mutual cooperation (Pul serang) values, are now almost extinct (Djaha, 2003). The low level of participation is due to the fact that village governments are less involved in the village policy-making process (Tamunu and Djaha, 2013), unaccountable village governments (Holbala, 2015) in managing village finances; (2) All Village development programs and activities are expected to be sustained in a sustainable way by utilizing the natural resources and resources available in the village. The results of Boymau's (2014) study indicate that the limited authority of the village made the village lack sufficient space to develop programs and activities in a sustainable manner in optimally utilizing village resources. The limitation of authority caused by the many original authorities that have been lost due to the hegemony of the state, the village autonomy which should have been transferred has not been conducted by the Regent; (2) Preparation of village development planning has not been in accordance with the priority of community needs, potential, and value of local wisdom in the village (Tamunu, Djaha, 2014); (3) Development of transparency and accountability system in the implementation of Village Government and Development has not been well implemented (Holbala, 2015); (4) Empowerment of village social institutions and adat institutions has not been undertaken by district and village governments (Djaha, 2006; 2007); (5) The empowerment of community participation in village policy making through village consultation is not ignored by the village government (Tamunu and Djaha, 2014); (6) Improvement of quality and capacity of human resources of village communities has not been done by village and regency government (Djaha, 2007); (7) Public control room given in schools for the implementation of School Operational Assistance (BOS) funds through Technical Guidance (Juknis) Implementation of BOS has not been obeyed by the school and the community itself has not had the courage to correct the mistakes of the school on the grounds of teacher service on the students (Djaha, 2012).

All the results of the above-mentioned research indicate that villagers have not been empowered in the planning, implementation, monitoring and development stages in the village. Therefore, a government effort to empower the village community is necessary to review the appropriate empowerment strategy. The determination of appropriate strategies should be based on an appropriate analysis of the strengths, weaknesses, opportunities, and threats that villagers are currently facing and facing, not based on logical/rational and theoretical analysis of bureaucrats or academics without accurate data and information from the village.

Social Capital. Fukuyama (2005: 21) provides social capital restrictions as a set of values or norms brought by group members within the community that enable cooperation among them. If community members believe that other members are trustworthy and honest, then they will trust each other. Trust is like a lubricant that makes the community or organization more efficient. The norms that produce social capital include the values of honesty, fulfillment of obligations, and take place mutually.

Robert Putnam (1993) defines social capital as a value of mutual trust between members of society on their leaders. Social capital is defined as a social institution that involves networks, norms, and social trusts that encourage social collaboration (coordination and co-operation) for the common good. It also implies that there is a need for social networks ("network of civic engagement") - the social ties/networks that exist in society, and the norms that drive community productivity. Putnam explains the meaning of horizontal association, not only that it gives the desired outcome but also undesirable outcomes.

Social capital with respect to elements such as trust, cohesiveness, altruism, mutual cooperation, networking, social collaboration has a great influence on economic growth through various mechanisms, such as increased sense of responsibility for the public interest, widespread public participation in the democratic process, society and the decline in violence and crime (Suharto, 2005b). The World Bank classifies social capital into six dimensions: (1) 
network/relationships and groups in society, (2) solidarity and trust in society, (3) mutual cooperation, (4) communication and information, (5) cohesion/community members, (6) policy and empowerment in society. The real form of social capital in the form of social relations/interaction, customs and local customary values, tolerance, willingness to hear (empathy), honesty, local wisdom and local knowledge, social networking and social leadership, trust, togetherness and loyalty, community participation, community independence.

The objectives of empowerment social capital are as follows: (1) The empowerment of autonomy, social capital becomes a force for the community to be self-reliance and ability to manage its own interests; (2) Empowerment in terms of cooperation, social capital helps communities to manage social risks and can increase the capacity of communities to prevent or respond to shocks; (3) Empowerment social networks, with social capital, community elements helping each other and managing risks based on informal relationships.

Local Institution. Esman and Uphoff (1988) argue that local Institutions / Organization is one of the important elements in rural development. This shows that without the existence of local institutions, bureaucracy, and participants, the infrastructure cannot be built or maintained. Public service cannot be done while the appropriate technology will not be maximally deployed and the government will not be able to maintain the information flow needed by the community. Based on its founding manner, there are two kinds of institution. The first is an institution that grows and develops spontaneously within the community itself, then the second is an institution that is formed by the government in the implementation of development programs.

Darling (1977) explains that indigenous people factor is the main determinant of development. Steive (1977) has proposed the implementation of the Minimum Package Project (MPP) program by the World Bank, USAID and SIDA in Etopia who prefer to create a new organization instead of utilizing existing traditional organizations that ultimately fails is an example of how important indigenous/local organization in the development success itself.

Stive exhibits that local institutions still play an important role in village development. Therefore Imron Ali and Riyadi Soepraptosuwondo (2002) recommend that (1) in the context of village development the government should use local institutions as the spearhead of development that implements various development programs. So the government no longer needs to establish new institutions or implementing groups, because existing local institutions are much more aware of the life of the local community; (2) The government should prioritize the development pattern based on the strength or self-reliance of the community by making the traditional local institutions that have been rooted in the life of the community as the basic implementation.

\section{METHODS OF RESEARCH}

This article is part of a research on island village empowerment strategies conducted in Desa Pulau Buaya, Alor Nusa Tenggara Timur Regency (2016). This paper focuses on 'Empowerment social capital and local institutions' which is expected to be done by community actors in rural development. (Eko, 2004: 256). Social capital is understood as the value used as the basis of strength in working together (community). The value in question is solidarity (loyalty due to a similar situation) which encourages the members of the community to be involved in various activities in the village together. Such social capital needs to be maintained, maintained/protected as village development capital. All parties are responsible in this regard including the Government, Provincial Government, Regency Government, Village Government and local institutions located in the village. This paper focuses on local institutions as parties who are expected to maintain and empower social capital. The local institutions referred to are adat institutions and religious institutions.

The method used in data collection is Focus Group Discussion (FGD) by presenting the village government (village head, Chairman of BPD), LPMD chairman, customary leaders, religious leaders, village community representatives, youth groups and women's groups. Data were analyzed by pattern matching/categorization. 


\section{RESULTS AND DISCUSSION}

Pulau Buaya is a village whose territory covers one island called Pulau Buaya. Its boundaries are surrounded by sea. This island village is located in Northwest Alor Regency with $2.11 \mathrm{Km}^{2}$ or $211 \mathrm{Ha}$ and is the third smallest area $(1.95 \%)$ after Desa Lewalu Village $(1.02 \%)$ and Lefokisu Village $(1,37 \%)$ from Northwest Alor Regency with $107.95 \mathrm{Km}^{2}$ or $1,795 \mathrm{Ha}$ area.

Regency Capital (Kalabahi) distance from the village is $40 \mathrm{Km}$, while from the Northwest Alor Regency Capital (Kokar) is $10 \mathrm{Km}$. Transportation method used from both cities requires land and sea transportation or sea transportation only. Visitors hailing from Kalabahi mostly use land transportation (Bemo -small car/taxi- or motorcycle) to the new O'a Mate Village. Then they cross watery region using the motorboat, and vice versa. Visitors hailing from Kokar are able to use land and sea transport. They can also go directly using motor boat directly from Kokar to Pulau Buaya. Travel time varies according to road conditions. Similarly, the sea travel time is highly dependent on the state of currents and wind.

Based on Northwest Alor Regency data in the Year 2015, there are 1,221 inhabitants, inhabiting an island with an area of $2.11 \mathrm{~km}^{2}$ with a population density of 278.67 inhabitants / $\mathrm{Km}^{2}$. There is more female population (642 inhabitants) than male population (579 inhabitants). There are 263 households with an average member of five-person in each household.

Empower Social Capital through Religious Institution. All villagers are Muslims. In the middle of the village stands a magnificent mosque built by the villagers themselves. The mosque was built by self-reliance villagers who rely on community participation. All building materials were brought by the villagers. Each head of the family shares a certain amount of burden. Community participation in the construction of the mosque is very high. Community's willingness is sincere. Sincerity based on the belief that the activity is considered a form of 'worship'. In addition, for people who are not engaged in work, will be punished by embarrassment as a result of social sanctions from other members of the community in the form of verbal assault.

In addition to involvement in providing building materials and energy, there is also involved in the provision of food and beverages. Arrangements to provide food and drinks are done according to each tribe / Kabila. Every day the labors are provided with food twice at breakfast and lunch. Each tribe / Kabila is competing to provide the best food and drink for the people involved in mosque construction. Sincerity provides the best food for workers is also based on 'worship value'. Each member of tribe / Kabila comes provides with their respective ability. Some bring rice, corn rice, 'corn katema', or cassava / sweet potato. An interesting matter to be noted is that varied types of food are not a source of slander, but it is complimentary. There is no 'shame' among mothers for providing a variety of foods, but the embarrassment arises when not bringing food to the active site during meal time. The acceptance of each other's highly varied existence is a very high-value social capital in the village community grown through local institutions.

Solidarity capital is also shown through the development of Madrasyah Ibtida'iyah (MI) and Masrasyah Tsanawiyah (MTs). Both schools were originally built by self-reliant villagers, therefore community participation is quite high. The high participation is also supported by the value of 'worship'. The community believes that sending their children to the correct understanding of religion is a parent's obligation so that any support requested by the school/teacher, the parent complies with it.

Social capital in the form of solidarity is also evident in religious events such as circumcision, mass circumcision, and marriage. Specifically, both types of religious activity are already mixed with the customs. However, community solidarity in both events is closer to the value of gotong-royong. Foodstuffs and animals brought by one family/tribe to provide the party will be 'recorded'. There are officers (officiates with special duty) appointed by the party organizers to pay attention to the amount of rice and the size of the animals brought by the tribes in the village. It is this officer who reports to the party organizer about the presence of 
all tribes in giving support during the party. The family who organizes the party then listens and records it - formerly only with memory, without a note - if at any time the tribe in question organizes circumcision or marriage events, the family/tribe will provide food (rice and animals) which was equal or more than the amount they previously received.

Empower Social Capital through Adat (Customary) Institution. Adat is understood as a rule (deeds) that are commonly obeyed or performed since time immemorial; habits or ways (behavior) that has become a habit. customs are understood as all rules (actions) that have become a habit for generations. Many social capital values are the practice of village customs. There is even custom in religion, meaning that in the religious events such as mass circumcision and marriage possess enforced rules that are obeyed from generation to generation.

In the wedding ceremony (akad nikah) involves a series of customs that need to be obeyed such pre-marriage (proposal, the evening event tablig), the ceremony itself, and bride procession to the groom's house. The series of weddings that have become the traditions of the community of Pulau Buaya involve all families residing in the island. This is because all villagers of this island are still related by blood/family relationships. Large or small events almost always involve all households in the village.

In addition to customary marriage, the tradition of building a house also involves families who have a kinship (genealogical). The construction of houses involving all families with very high blood relation is the development of 'Rumah Adat' (Customary House) or 'Rumah Suku' (Tribal house). Each tribe is involved in constructing the tribal house. Failure to do so would bring shame and the disruption of self-esteem in the family. Social sanction in society effectively deters villagers from evading various activities both religious and in every custom activity.

Community Participation in Village Development by Village Government or High-Level Government. Development carried out by religious institutions and customary institutions in the villages, the participation of the community is very high. Should the development initiated by the Village Government, or the upper-level government (district, province, central government), the participation of the community is low. There are many examples of cases that prove this. A number of case examples of community participation in development initiated by religious and adat institutions have been previously mentioned. The following are examples of cases of community participation in government-initiated development.

There are a number of cases experienced by the district or provincial officials who visited the village of Pulau Buaya. These employees often have difficulty in crossing to the Pulau Buaya. There are a number of motorboat owners are reluctant to accept a ride, even with monetary offers. These boat owners do not like the government. The reasons vary; Some say because the government often makes promises but rarely fulfilled. Especially promises during the campaign ahead of the election of regents and vice-regents. The village chief of Pulau Buaya also acknowledged this community statement. Regent candidates have campaigned in Pulau Buaya. The community asks for help for the coastal erosion of Pulau Buaya. The candidate replied that the villagers only need to visit regency office to request 100-200 sacks of cement directly and forgo bureaucracy. After the candidate is elected a regent, Pulau Buaya community visited the regent official house and convey the intent. The Bupati then asked the community to submit it to the office to be processed. The people were disappointed and returned to the village without bringing the results as promised.

Another case is when the government programmed Jambanisasi (building a toilet in villages) in 2015 with village funding from the 2015 State Budget. There are 260 households in the village, but only 67 houses possess toilets. A total of 193 houses that do not possess toilet facility. Several houses residents use the toilet facility together, but most use the coast which disturbs the surrounding. All building materials - stone, sand, cement, wood, iron, zinc, nails, and others - are provided by the village government in cooperation with a third party. It is expected that the work will be completed self-reliance by the community. In reality, it didn't occur as expected. Finally, the village government reallocated funds for hired labor. Wages prepared for hired labors are deemed inadequate, requiring participation from homeowners, at least providing food and drink. A number of people welcomed the labors well, but there 
were still a number of households who refused on the grounds that the workers had been paid. Until the end of 2015, there are 14 houses that do not complete the work of the toilet because the residents of the house do not participate in the work. Everything is left to the hired labor. Pulau Buaya Kaur Village Government explained that villagers participation in the completion of government programs no longer self-supporting but had to be paid for.

In 2016 the government programmed the construction of road concrete in the village for 800 meters. The work was completed with participation, but all were paid with village funds. The activity was conducted smoothly. Without payment, the construction would not be finished (Kaur Village Government of Pulau Buaya, August 2016). Explanation of the head of this affair is also recognized by the Village Head and Chairman of BPD Pulau Buaya. Amin, a villager also admitted it. Described by this citizen that now everyone counts economically. Villagers used their time optimally. A day's fishing would result in Rp.100.000 or more. Should the government offers jobs with wages below than that, the public does not accept. Minimum wages in the village is Rp.75.000.- per day. Since the daily worker is paid for that amount, the village government offers a 'borong' (taking the entire stock) system so that a working group of 10 people completes a 100-meter rebate concrete at a price of Rp $30,000,000$. It is completed within 5 working days. This is the condition of the participation of the villagers of Pulau Buaya in completing the village government program.

\section{CONCLUSION AND SUGGESTIONS}

One of the main supporting values of development in the village is social capital (in the form of values of solidarity, participation, mutual cooperation), in addition to economic capital, human capital, and other capital. The values of social capital need to be maintained. One strategy of empowering rural communities (social capital) can be done through empowerment the role of local institutions that exist in villages such as religious and customary institutions.

With regard to the empowerment of social capital through local institutions can be put forward several recommendations:

1. Social capital in the village is still very strong to mobilize villagers in various activities in the village. In order to ensure the successful implementation of village development, the government should take advantage of local institutions as the spearhead of development that implements various existing development programs. The government no longer needs to establish new institutions or implementing groups, because existing local institutions are much more aware the local community;

2. The government should prioritize the development pattern that relies on the strength or self-reliance of the community by making local traditional institutions that have been rooted in community life as a basic implementation.

3. If the village government runs itself and ignores local institutions in the village, a sign of the destruction will be experienced in the village.

\section{REFERENCES}

1. Ali, Imron H.R.; Riyadi, Soepraptosuwondo. 2002. Peran Institusi Lokal Dalam Pembangunan Desa (Suatu Kajian Tentang Peran Lembaga Tahlil Dalam Pembangunan Desa di Desa Simorejo Kecamatan Kanor Kabupaten Bojonegoro), Unpublished Thesis, Universitas Brawijaya.

2. Boymau, Yesaya, 2013, Kewenangan Desa (Studi Kasus Di Desa Tunua Kecamatan Mollo Utara Kabupaten Timor Tengah-Selatan), Unpublished Thesis, Public Administration Department, Universitas Nusa Cendana.

3. Chambers, Robert, 1987. Pembangunan Desa Mulai Dari Belakang, LP3ES, Jakarta.

4. Eko, Sutoro, 2004. Reformasi Politik dan Pemberdayaan Masyarakat, APDM Press, Yogyakarta.

5. Darling, Roger, 1977, A Return to Valid Development Priciples, International Development Review. 
6. Djaha, Ajis Salim Adang; Kamahi, Umrah; Panara, Mohammad Arief; Kamahi, Syahlan. 2003. Identifikasi Adat Istiadat dan Lembaga Adat Yang Menunjang Pelaksanaan Otonomi Desa di Kabupaten Alor, Unpublished Research Result, FISIP Undana with the Government of Kabupaten Alor, Kupang.

7. Djaha, Ajis Salim Adang. 2006. Persepsi dan Sikap Masyarakat Terhadap Refungsionalisasi Adat Istiadat Setempat Dalam Pemilihan Kepala Desa (Studi Kasus Persyaratan Pemilihan Kepala Desa di Desa Aimoli Kabupaten Alor, Jurnal Administrasi Publik, Volume 5 Nomor 1, October 2006, Kupang.

8. 2006. Kapasitas Desa Dalam Pelaksanaan Otonomi Desa Di Kecamatan Northwest Alor Kabupaten Alor, Jurnal Administrasi Publik, Volume 5 Nomor 1, October 2006, Kupang.

9. 2007. Desa Adat (Sebuah Upaya Penyelenggaraan Pemerintahan Desa Berdasarkan Adat Istiadat Setempat, Studi Kasus di Desa Bampalola Kecamatan Northwest Alor Kabupaten Alor), Jurnal Pluralis Jurnal IImu-IImu Sosial, Volume V Nomor 2, April 2007, Kupang.

10. 2012. Kontrol dan Akuntabilitas Birokrasi Dalam Pelayanan Pendidikan Dasar di Kabupaten Alor, Unpublished Dissertation, Universitas Hasanuddin.

11. Holbala, Marten, 2015. Akuntabilitas Pengelolaan Alokasi dana Desa di Kecamatan Kupang Barat Kabupaten Kupang, Studi Kasus di Desa Kuanheun, Bolok dan Nitneo, Unpublished Thesis, Universitas Nusa Cendana.

12. Ife, Jim \& Tesoriero Frank, 2008. Community Development - Alternatif Pengembangan Masyarakat di Era Globalisasi, Pustaka Pelajar, Yogyakarta.

13. Esman, Milton J., and Uphoff, Norman T., 1988, Local Organizations: Intermediaries in Rural Development, Cornell University Press, Itacha, and London.

14. Fukuyama F.2005, Trust, Jakarta: Penerbit PT. Gramedia Pustaka Utama.

15. Fukuyama, Francis (1995), Trust: The Social Virtues and The Creation of Prosperity, New York: theFree Press

16. Putnam, Robert. 1993, The Prosperouse Community : Sosial Capital and Publik Live dalam The American Prospect Volume 13

17. Stieve, Benedict, 1977, Social Soundness Analysis of Ethopia's Minimum People Program II, Paper Prapared for USAID, Washington DC.

18. Suharto, Edi (2005b). Membangun Masyarakat Memberdayakan Rakyat: Kajian Strategis Pembangunan Kesejahteraan Sosial dan Pekerjaan Sosial, Bandung, Refika Aditama.

19. Sujatmiko, Budman; Zakaria, Yando. 2015. Desa Kuat, Indonesia Hebat, Diterbitkan atas Kerja sama rumah suluh-Pusat Studi Pedesaan-Penerbit Pustaka Yustisia, Yogyakarta.

20. Tamunu, Lenny, M., \& Djaha, Ajis, Salim, Adang, 2013. Kapasitas Badan Permusyawaratan Desa Dalam Pelaksanaan Otonomi Desa di Kecamatan Taebenu Kabupaten Kupang, Jurnal Administrasi Publik, Volume 12, No. 1. 